\title{
Measuring the Benefits of ICTs in Social Enterprises: An Exploratory Study
}

\author{
Marcelo Okano ${ }^{1}$ \\ marcelo.okano@fatec.sp.gov.br | (10 0000-0003-1680-7821 \\ Celi Langhi ${ }^{1}$ \\ celi@infolearning.com.br | (10 0000-0002-5527-2412 \\ Rosinei Batista Ribeiro ${ }^{1}$ \\ rosinei1971@gmail.com | (10 0000-0001-8225-7819
}

\begin{abstract}
The study presented in this article aims to identify what are, in fact, the social missions of companies called "social companies", and what are the benefits obtained from the use of ICTs by these companies. The research methods employed were bibliographic research and case study. The bibliographic research was elaborated from a systematic analysis and the use of a theoretical framework related to performance indicators, as proposed by Hutchinson and Molla (2009). The case study was carried out based on four social companies, with which observations were made in loco, application of interviews and analysis of the respective websites. The results indicated that the social mission of this type of company can be explained by the use of six indicators: access to markets, income generation, employment opportunities, social training, strengthening of relations with the sponsor and social outsourcing; and that these indicators require the use of ICTs to be developed. It is concluded that, if at least one of the indicators is present in these companies, ICTs can bring some kind of benefit.
\end{abstract}

\section{KEYWORDS}

Social Enterprises, Information and Communication Technologies, Indicators for Social Mission 


\section{INTRODUCTION}

The world is undergoing constant transformations that can change the trajectory and history of organizations, illustrated by the first and second industrial revolutions, whose main values were economic, and the information revolution, in which the main value is information. Other conceptualizations of value created were accepted by the market, for example, social value, which gave rise to new types of organizations such as companies, businesses, and social enterprises.

Organizations that aim to solve social problems in an efficient and sustainable manner, mainly with regards to their market mechanisms and financial aspects, currently receive various names: social companies, inclusive business, hybrid organizations, and social business, among others (COMINI et al., 2012).

Despite the growing academic interest in social enterprises, there is no conceptual agreement since this type of definition is made complex by the heterogeneous manifestations of social enterprise in practice. In addition, although they influence each other, theoretical debates among scholars do not necessarily reflect discussions and debates among professionals (DERAEDT, 2009).

Another difficulty found in the literature is to know what are the benefits obtained by social companies from Information and Communication Technologies (ICTs) and how to measure them.

In the case of social organizations, where the social mission has driven programs and activities, there is still little thought on how to measure the achievement of their social objectives. Some efforts have been made to develop tools to assess the impact of social enterprises in what is commonly known as "social accounting" (HUTCHINSON; MOLLA, 2009).

The motivation for conducting this research occurred in view of the importance of social organizations for the current social and economic context and the importance of using ICTs to encourage this type of activity with regard to both the constitution of new social companies, as well as the allocation of public and private investments to assist in its development and sustainability.

The objective of this research was to analyze the benefits obtained by the use of ICTs by social companies, from the use of a theoretical framework related to performance indicators, as proposed by Hutchinson and Molla (2009).

We used the case study as a research method, according to Yin (2010), who points out the importance of having at least three different types of evidence sources when using this type of method. For this reason, data were collected through on-site observation, interviews with professionals from these companies, and also through the analysis of information on the respective websites.

The survey results indicated that social enterprises must be understood from their social mission. Six indicators can be used to carry out this type of analysis: access to markets, income generation, employment opportunities, social training, strengthening relations with the sponsor and social outsourcing. It was also found that the development, application, and analysis of these indicators require the use of ICTs. These results allowed us to conclude that ICTs can bring benefits to social organizations as long as at least one of the indicators studied is present in their activities.

This study contributes to the development of new research on the importance of ICTs in the context of social enterprises in general, as well as on the importance of developing indicators that assist in diagnosing the types of technological resources that may be used and that will require investments by both creators and investors of this type of company. 


\subsection{SOCIAL BUSINESS CONCEPTS AND DEFINITIONS}

The concept of social enterprises emerged as a consequence of the Italian cooperative movement and then of the movements of Belgium and the United Kingdom in the 1990s, as a result of the organization of cooperatives (Defourny; Nyssens, 2010). However, it was only in 2002 that the British government defined social enterprises as a business, with basically social purposes, and all the profit generated should be reinvested according to the purpose of the business or in the community. (DTI, 2002).

The formation of social enterprises in Europe originated with the provision of public services at a lower cost, as well as the creation of jobs for poor people who were not employed (BORZAGA; DEFOURNY, 2001).

To deepen the studies on social enterprises, a systematic literature review was carried out, as shown in Chart 1.

Chart 1

Definitions of social enterprise publications

\begin{tabular}{|c|c|}
\hline Definition & Authors \\
\hline $\begin{array}{l}\text { Social enterprises refer to non-profit organization, revenue-generating ventures or social } \\
\text { ventures that create social impact. }\end{array}$ & Dees $(1998)$ \\
\hline $\begin{array}{l}\text { Social enterprise is an organization with a social mission that works as commercial } \\
\text { and innovative enterprises and are financially self-sufficient to enable the creation, } \\
\text { dissemination and distribution of social or environmental value. }\end{array}$ & $\begin{array}{l}\text { Granados et al. } \\
\qquad(2001)\end{array}$ \\
\hline $\begin{array}{l}\text { A social enterprise is a type of business with a social mission, with profits being } \\
\text { reinvested in the company itself, rather than being distributed to shareholders. }\end{array}$ & DTI (2002) \\
\hline $\begin{array}{l}\text { In Europe, social enterprise is defined by the Organization for Economic Cooperation } \\
\text { and Development (OECD) as any private activity or operation with community } \\
\text { interests. Its main objective is not to maximize profits, but to obtain certain economic } \\
\text { benefits and social objectives. }\end{array}$ & Kerlin (2006) \\
\hline $\begin{array}{l}\text { The main objective of a social enterprise is to serve social areas that have been neglected } \\
\text { by the government, generating social value and non-profitability. }\end{array}$ & Nicholls (2006) \\
\hline $\begin{array}{l}\text { They are organizations with a clear objective whose purpose is to help the community, } \\
\text { creating citizens, and the substantial benefits of capital investment are limited. }\end{array}$ & $\begin{array}{l}\text { Defourny; Nyssens } \\
\quad(2008 \mathrm{a})\end{array}$ \\
\hline $\begin{array}{l}\text { "They are not private organizations that offer goods or services directly related to their } \\
\text { explicit objective of benefiting the community". }\end{array}$ & $\begin{array}{l}\text { Defourny; Nyssens } \\
\text { (2008b) }\end{array}$ \\
\hline $\begin{array}{l}\text { An organization that uses business to fulfill a social objective and adopts various } \\
\text { strategies to solve social problems and opportunities. }\end{array}$ & Alter (2007) \\
\hline $\begin{array}{l}\text { The social enterprise is a non-profit organization, with a sustainable and scalable } \\
\text { income stream generated from social activities. }\end{array}$ & Brozek (2009) \\
\hline $\begin{array}{l}\text { Although the organization of social organizations is based on a non-destructive and } \\
\text { dividend-free basis, social enterprises are different from NGOs and non-governmental } \\
\text { organizations. }\end{array}$ & Yunus et al. (2010) \\
\hline $\begin{array}{l}\text { They are organizations that seek to solve social problems by applying business practices } \\
\text { and principles. }\end{array}$ & Dacin et al. (2010) \\
\hline They are private organizations that use strategies to achieve society-oriented goals. & Dacin et al. (2010) \\
\hline $\begin{array}{l}\text { Social Business Knowledge Network (SEKN) defines a social enterprise as an organization } \\
\text { that generates social changes through market activities. }\end{array}$ & Comini et al. (2012) \\
\hline
\end{tabular}


Chart 1

Cont.

\begin{tabular}{|l|c|}
\hline \multicolumn{1}{|c|}{ Definition } & Authors \\
\hline $\begin{array}{l}\text { They solve social problems through commercial organizations, combining innovation } \\
\text { and the resources of a traditional company with efficiency. }\end{array}$ & Battilana et al. (2012) \\
\hline $\begin{array}{l}\text { As the name suggests, social companies employ multiple stakeholders to carry out social } \\
\text { missions through commercial companies. }\end{array}$ & $\begin{array}{c}\text { Smith; Gonin; } \\
\text { Besharov (2013) }\end{array}$ \\
\hline $\begin{array}{l}\text { In social enterprises, the social mission defines the purpose of the business and vice } \\
\text { versa. }\end{array}$ & $\begin{array}{c}\text { Smith; Gonin; } \\
\text { Besharov (2013) }\end{array}$ \\
\hline $\begin{array}{l}\text { The social enterprise is an organization that combines commercial and social guidelines } \\
\text { and operates in the gap between the market and the country. }\end{array}$ & $\begin{array}{c}\text { Alegre; Berbegal- } \\
\text { Mirabent (2016) }\end{array}$ \\
\hline $\begin{array}{l}\text { Social enterprises give rise to new methods and innovative solutions to social problems } \\
\text { and a better way to integrate employees and customers. }\end{array}$ & $\begin{array}{c}\text { Konsti-Laakso } \\
\text { et al. (2016) }\end{array}$ \\
\hline
\end{tabular}

Source: Prepared by the authors from the systematic review.

Based on the systematic review, it is possible to observe that there is no consensus regarding the concepts of social enterprises. However, it is noted that, since the first studies, (DEES, 1998; GRANADOS et al., 2001; DTI, 2002; NICHOLLS, 2006) there is already a concern with the generation of value or some kind of impact on society.

It is also possible to observe that social enterprises are at the service of the community, especially with regard to: economic solutions for exclusion, unemployment, and other social problems (KERLIN, 2006; DEFOURNY; NYSSENS, 2008 a e b; ALTER, 2007; DACIN et al., 2010; SMITH; GONIN; BESHAROV, 2013; KONSTI-LAAKSO et al., 2016); selfsustainability(YUNUS, 2007; BATTILANA, LEE, WALKER, DORSEY, 2012; ALEGRE; BERBEGAL-MIRABENT, 2016; RIDLEY-DUFF \& BULL, 2018); and generating social changes (COMINI et al., 2012).

Next, the main denominations attributed to social companies are analyzed.

\subsection{DENOMINATIONS OF SOCIAL ENTERPRISES}

Social companies receive various names in specialized publications: Social Enterprise, Inclusive Enterprise, Social Impact Company; Mixed Organization; Social and Cooperative Technology. These definitions will be defined below.

\subsection{1. a) Social businesss}

According to research by Comini et al. (2012), the origin of the social enterprise is originates with the article by Prahalad and Hart (2002) that highlights the base of the wealth pyramid (BoP). These authors were the first to highlight the role that multinational companies must play in alleviating socio-environmental problems. However, the actions take place in a limited way and, in some cases, are totally ineffective, and cannot be used to improve living conditions.

In this way, the most significant contribution of multinational companies will be to offer the public innovative services and products that meet demands totally different from their focus, without departing from the trend of generating profits and distributing dividends to shareholders.

\subsection{2. b) Inclusive business}

The term is recurrent in developing or emerging countries in Asia or Latin America and highlights the use of market practices aimed at reducing poverty and changing the social conditions of 
marginalized groups (GUPTA et al., 2017) and achieving social inclusion through consumption (PRAHALAD; HART, 2002; PORTER; KRAMER, 2011; REFICCO, 2011). These initiatives promoted inclusive capitalism, that is, many people began to have access to the market economy, indicating that this is a model that should be encouraged by large corporations.

\subsection{3. c) Social impact business}

The social impact business is an organization that aims to produce social impact by offering products and services that reduce the vulnerability of low-income people while bringing financial returns (Barki et al., 2015). Petrini et al. (2016) defines as an organization that aims to solve needs related to social problems, either to provide products and services, or to include individuals or groups. These companies must be financially self-sustaining and profit sharing is optional.

\subsection{4. d) Hybrid organization}

The concept of hybrid organization began in the 1990s, after several NGOs made great demands for their microfinance services. These organizations determine that the only way to meet this need is to divide the business organization. These new organizations combine the "logic" of two previously independent institutions: a development logic (instructing its mission to help the poor) and a banking logic that requires sufficient profits to sustain continued operations and fulfill fiduciary duties (BATTILANA; DORADO, 2010).

Organizations are classified as:

- A mixed non-profit organization uses its own financial resources to guarantee, within its social mission, the continuity of its own business. These funds come from donations or charities (LAPOWSKY, 2011), as associations and foundations (BUCHKO, 2018).

- Mixed for-profit organizations, according to Santos et al. (2015), follow social missions while operating with commercial business models and pave the way for new ways to achieve social impact. Although social enterprises have high hopes, they are also fragile organizations that must fulfill their social mission and meet market demands.

\subsection{5. e) Social Tech}

Technological progress has provided the possibility of using technology in various fields, leading to solutions in the social field. According to reports by Arena et al. (2018), social challenges have intensified, affecting the demand and supply of social technological innovation. The combination of this development and the decline in overall personal well-being has resulted in innovative organizations that can use a combination of technology and social innovation to seize opportunities.

Social technology startups, called Social Techs, design and develop solutions focused, in a financially sustainable way, on meeting social needs (Arena et al., 2018) and are gradually characterized by trying to use advanced technologies to meet different needs (Millard ; Carpenter, 2014). The evolution of these companies is due to the need to face the social challenges brought by the new market opportunities and the possibility of taking advantage of the opportunities, to explore the potential synergy between technology and social innovation, and the new incentives provided by the government (Arena et al., 2018).

\subsection{6.f) Cooperatives}


Robert Owen (1771-1858) is the father of the cooperative movement, since the mid-19th century, cooperatives were the pioneers of commercial activity in the social field, when they already played a role in financing the socio-economic agenda (ALTER, 2007).

The cooperative is defined by the Alliance of International Cooperatives (ACI, 2018) as companies which are centered, controlled, and directed by people, aiming at realizing the economic, social, and cultural needs and aspirations of its members, basedon the values of self-help, author responsibility, democracy, equality, equity and solidarity. In the tradition of its founders, members of the cooperative believe in the ethical values of honesty, openness, social responsibility and care for others (ALTER, 2007).

An important factor for social enterprises, regardless of the nomenclature they receive, is the use of Information and Communication Technologies (ICTs) in their processes, mainly with regard to customers and suppliers, as will be presented below.

\subsection{Proposal FOR ICT INDiCATORS IN SOCIAL ENTERPRISES}

As Information Technologies (IT), Information and Communication Technologies (ICTs) and social enterprises become engines of current economic growth, new opportunities for new business models for communities in developing countries arise and enable research in these areas (HUTCHINSON; MOLLA, 2009).

According to Prahalad and Hart (2002), a way to lower company costs to serve customers at the bottom of the pyramid will inevitably lead to greater use of IT to develop production and distribution systems.

IT, of course, can help automate business processes and make them leaner and less costly. The internet itself democratizes access to information for all social classes.

ICTs, in turn, are seen as promoters of new exchange mechanisms that allow companies in developing countries to compete equally in world markets (HUTCHINSON; MOLLA, 2009).

Although the position of most multilateral agencies is optimistic about the potential of ICTs to respond to the development needs of companies in developing countries in general and Small and Medium Enterprises (SMEs) in particular, it is recognized that personalized initiatives, such as electronic commerce, are better adapted to ICTs to achieve development goals (HUTCHINSON; MOLLA, 2009; DAVISON, HARRIS, VOGEL, 2005; HEEKS, 2002).

However, it is important to analyze that the simple use of IT or ICTs is not enough to evaluate results and impacts. For that it is necessary to use a framework.

\subsubsection{Framework}

Hutchinson and Molla (2009), based on studies by Alter (2007), developed research on how social enterprises use ICTs to achieve their dual mission and how they, in turn, measure success. In considering how to measure impact, the investigation examined a number of areas, including livelihood and capacity structures, and current work in the field of ICTs.

To assess the impact that ICTs can have on social enterprises, Hutchinson and Molla (2009) used a framework, based on research by Alter (2007), which provides an overview of the research structure and the main concepts to be explored. The study considered how social companies 
use ICTs to achieve their dual mission and how they, in turn, measure success. In considering how to measure impact, the investigation examined a number of areas, including livelihood and capacity structures, and current work in the field of ICTs.

The authors proposed three main research questions for the study. To fully understand the variables of these questions, several questions have been proposed to further clarify the problem.

- Question 1: What shapes the framework for ICTs by social enterprises?

This issue involves the identification of institutions, their position (or role), and forms of influence. Specific questions include: who are the institutions that influence social enterprises? Do they belong to an intermediary body that promotes the goods / services of social enterprises? What is the nature of the interaction, that is, the form of institutional intervention, between institutions and social enterprise?

Chart 2 provides the definition of the main constructs involved in this research question.

Chart 2

Constructs involved in question 1

\begin{tabular}{|c|l|l|}
\hline Construct & \multicolumn{1}{|c|}{ Definition } & \multicolumn{1}{|c|}{ Example } \\
\hline External institutions & $\begin{array}{l}\text { Formal institutions, organizations and } \\
\text { associations that operate the company } \\
\text { externally }\end{array}$ & $\begin{array}{l}\text { Donors, Associations, Private sector, } \\
\text { NGOs, etc. }\end{array}$ \\
\hline Institutional roles & $\begin{array}{l}\text { Three roles identified in the research course } \\
\text { that typifies institutional interaction }\end{array}$ & Initiator, intermediary, reseller \\
\hline Forms of influence & Types of influence by external actors in SEs & $\begin{array}{l}\text { Funds, equipment, training, } \\
\text { systems development, staff / } \\
\text { volunteers, technical assistants, etc. }\end{array}$ \\
\hline
\end{tabular}

Source: Hutchinson; Molla (2009) adapted from Alter (2007).

- Question 2: How do social companies use ICTs?

This research seeks to establish the current use and penetration of ICTs by social enterprises. The question explores the use of ICTs by social enterprises in two main dimensions - internally and externally. Internally, it was examined to what extent social companies are using ICTs in the area of finance, administration, and production processes. Externally, the use of ICT with suppliers and customers was explored, as well as the business processes that support these keyrelationships.

Chart 3 offers a definition of the main constructs of question 2. 
Chart 3

Constructs involved in question 2

\begin{tabular}{|c|l|l|}
\hline \multicolumn{1}{|c|}{ Construct } & \multicolumn{1}{|c|}{ Definition } & \multicolumn{1}{c|}{ Example } \\
\hline ICTs & $\begin{array}{l}\text { Information and communication } \\
\text { technology }\end{array}$ & $\begin{array}{l}\text { Office computer network, } \\
\text { Landline Phone, Fax, Cellular, } \\
\text { Email, PCs, Internet, Firewall, } \\
\text { Website, Server for platform }\end{array}$ \\
\hline ICT applications & ICT applications & $\begin{array}{l}\text { Office Suite, Design Packages, WEB } \\
\text { development tools, Database, etc. }\end{array}$ \\
\hline External business & $\begin{array}{l}\text { Functions that operate internally as } \\
\text { processes, procedures, administration } \\
\text { and management to achieve improved } \\
\text { efficiency }\end{array}$ & $\begin{array}{l}\text { Internal Communication, Business as } \\
\text { Process, Procedures, Administration, } \\
\text { External Business Functions }\end{array}$ \\
\hline & $\begin{array}{l}\text { Functions that operate outside the } \\
\text { organization with external entities to } \\
\text { improve external relationships and } \\
\text { increase results }\end{array}$ & $\begin{array}{l}\text { External communication with } \\
\text { customer and supplier, Collaborative } \\
\text { product design, etc. }\end{array}$ \\
\hline
\end{tabular}

Source: Hutchinson; Molla (2009) adapted from Alter (2007).

\section{- Question 3: Do ICTs benefit social enterprises?}

This question assesses how social companies are using ICTs to achieve their dual social and business mission and offer benefits to target communities. As such, question 3 is based on the assumption that the successful use of ICTs depends on the benefits perceived and delivered in the real world.

In Chart 4, it is possible to see definitions and examples for constructs as beneficiaries, forms of support, economics and social audit and social mission indicators. From the knowledge of these constructs it is possible to analyze the organizational models of social companies.

Chart 4

Constructs involved in question 3

\begin{tabular}{|c|l|l|}
\hline Construct & \multicolumn{1}{|c|}{ Definition } & \multicolumn{1}{c|}{ Example } \\
\hline Beneficiaries & $\begin{array}{l}\text { Target community that } \\
\text { benefit from SEs }\end{array}$ & $\begin{array}{l}\text { People with disabilities, Women, Street children, Orphans, } \\
\text { People living with HIV / AIDS, Youth, Unemployed, } \\
\text { Trafficking survivors, Villagers, Farmers }\end{array}$ \\
\hline $\begin{array}{c}\text { Forms of } \\
\text { Support }\end{array}$ & $\begin{array}{l}\text { Ways by which social } \\
\text { companies provide support. }\end{array}$ & $\begin{array}{l}\text { Employment, training / skills development, as a consumer } \\
\text { for local producers (market creation), as a product trader for } \\
\text { local producers (intermediary), supplier for local producers, } \\
\text { business development assistance, products Design / Services } \\
\text { Development }\end{array}$ \\
\hline $\begin{array}{c}\text { Social } \\
\text { accounting and } \\
\text { social auditing }\end{array}$ & $\begin{array}{l}\text { Methods of measuring and } \\
\text { reporting organizational social } \\
\text { and ethical performance. }\end{array}$ & $\begin{array}{l}\text { An organization conducts a social audit on its accounts for } \\
\text { its stakeholders and is committed to following the audit } \\
\text { recommendations. }\end{array}$ \\
\hline Indicators & $\begin{array}{l}\text { A set of measures to } \\
\text { determine whether the social } \\
\text { mission is being accomplished }\end{array}$ & $\begin{array}{l}\text { Evaluate performance against Social Indicators, the ability } \\
\text { to employ more people, Recommendations from clients, } \\
\text { Recommendations from Beneficiaries, Awards / External l } \\
\text { Recognition from peers, specify Awards / Recognition from } \\
\text { Development Agencies / Donors }\end{array}$ \\
\hline
\end{tabular}

Source: Hutchinson; Molla (2009) adapted from Alter (2007). 


\subsubsection{Mixing the dual mission}

The new organizational model of social enterprises represents a change in the search for sustainable development at all levels, financial, social and environmental. This move towards a "mixed value proposal" reflects the integration of the dual mission, which is due to the very nature of social enterprises that ICTs directly benefit and assist in the global mission and the creation of the value proposal (HUTCHINSON; MOLLA, 2009).

The result of Hutchinson and Molla's research (2009) indicated that there has been a slight deviation from the dual mission originally perceived to the more mixed version which is reflected in Figure 1, which highlights the potential results of ICTs in social enterprises.

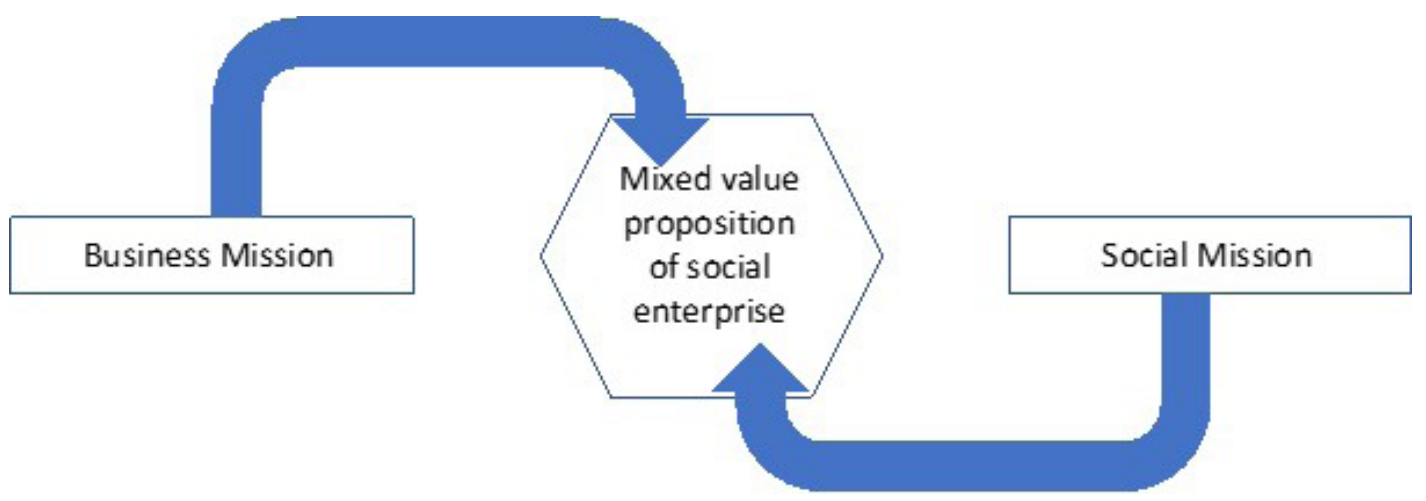

Figure 1. Mixed value proposition of social enterprise.

Source: Hutchinson; Molla (2009).

\subsubsection{Measurement of social impact}

The impact of social enterprises depends on the organization's mission, the social objectives it intends to achieve, and the impacts that can be measured as a result of business initiatives. A defining ambition of social endeavors is that they support those in the community who are in need (HUTCHINSON; MOLLA, 2009).

The social impact indicates a positive effect on the target population as a result of an intervention and can be measured. Social enterprises, like all development programs, have direct and indirect impacts. Alter (2007) provides some examples of the company's social impact measures and corresponding indicators. These have been adapted to identify the results (benefits) of ICT for social enterprises and, in particular, to assess the impact (attributable to ICT) of social enterprises in the target community.

\subsubsection{Identified benefits of ICT}

The benefits of using ICTs can be direct, as in the case of IT services with qualified labor; or indirect, as in the sales area, where there may be an intermediary qualified for ICTs. If one of the promised benefits of ICT is to increase the efficiency of internal and external operations, then it is important to measure how ICTs affect the operations of social enterprises.

The indicators used in Hutchinson's research; Molla (2009) are shown in Chart 5. 
Chart 5

Description of indicators in relation to market dimensions, income generation, opportunities, social training and strengthening of relationships with partners

\begin{tabular}{|l|l|}
\hline \multicolumn{1}{|c|}{ Indicator } & \multicolumn{1}{|c|}{ Description } \\
\hline Market access & $\begin{array}{l}\text { Through the application of ICT, are social enterprises able to } \\
\text { access new markets from which they would previously have been } \\
\text { excluded? }\end{array}$ \\
\hline Income Generation & $\begin{array}{l}\text { Do ICTs allow social enterprises to generate income due to their } \\
\text { use? }\end{array}$ \\
\hline Employment Opportunities & $\begin{array}{l}\text { Do beneficiaries of social enterprises due to ICT have job } \\
\text { opportunities? }\end{array}$ \\
\hline Social training & $\begin{array}{l}\text { By taking the experiential learning approach, can ICT be used to } \\
\text { simulate real life experiences and provide an advantage for skill } \\
\text { development? }\end{array}$ \\
\hline $\begin{array}{l}\text { Strengthening of relationships with the } \\
\text { Sponsor }\end{array}$ & $\begin{array}{l}\text { Do social companies strengthen their relationships with sponsors } \\
\text { with the use of ICTs? }\end{array}$ \\
\hline Social Outsourcing & $\begin{array}{l}\text { Does the social enterprise allow the outsourcing of any service due } \\
\text { to the use of ICT? }\end{array}$ \\
\hline
\end{tabular}

Source: Hutchinson; Molla (2009) adapted from Alter (2007).

\section{METHODOLOGY}

The research methods used to carry out the research presented in this article were a case study and a systematic literature review.

The "systematic review" method assists in the identification, knowledge, and monitoring of research development in specific areas of knowledge (MIGUEL et al., 2007). In this research, in addition to studies on social companies, it helped in studies on social business and ICTs.

The case study, as a research method, helps in the analysis of contemporary events, rich in different situations, which have many variables to be considered (YIN, 2010); sending the study to premises of critical realism and dynamics present in specific scenarios (EISENHARDT, 1989); and attention to concrete problems (STAKE, 1995).

Its use should assist in the identification of the case, in the justification of its choice, in the development of a theoretical perspective; the triangulation of different sources of evidence; contextualizing explanations of opposing theories in the analysis of results; and enabling the generalization of research theories.

The "Case study" method can refer to single or multiple cases, in addition to different levels of analysis, with qualitative and / or quantitative evidence (YIN, 2010). Usually, several methods of data collection are used together, such as documentary research, forms of observations, and collection instruments such as interviews and / or questionnaires, in order to provide descriptions, prove, or generate theories (YIN, 2010; EISENHARDT, 1989).

In this research, the "case study" method was applied to the analysis of benefit indicators provided by ICTs, according to the constructs reported in Charts 2, 3 and 4, which are based on the framework of Hutchinson and Molla (2009) adapted from Alter (2007 ). Qualitative evidence obtained through interviews, observations in the companies and analysis of the websites of the social companies, which were the focus of this study, were used. 


\section{RESULTS AND ANALYSIS}

Chart 6 presents the characteristics of the social companies surveyed and the answers to the

first question as an external institution, institutional role and forms of influence, which are the indicators based on the constructs of Chart 2 of the framework of Hutchinson and Molla (2009) adapted from Alter (2007).

Chart 6

Answers to question 1 of the surveyed social companies

\begin{tabular}{|c|c|c|c|c|c|c|}
\hline Company & $\begin{array}{c}\text { Occupation } \\
\text { area }\end{array}$ & $\begin{array}{c}\text { Type of } \\
\text { Company }\end{array}$ & City & $\begin{array}{c}\text { External } \\
\text { institution }\end{array}$ & $\begin{array}{c}\text { Institutional } \\
\text { role }\end{array}$ & $\begin{array}{c}\text { Form of } \\
\text { influence }\end{array}$ \\
\hline Copmed02 & Recycling & Cooperative & São Paulo & Private initiative & Initiator & Funds \\
\hline Hibmed02 & Culture & Hybrid & São Paulo & Private initiative & Intermediary & Funds \\
\hline Hibmed03 & Urban mobility & Hybrid & São Paulo & Private initiative & Reseller & Funds \\
\hline Negsocgr01 & Financial & Social Business & São Paulo & Private initiative & Intermediary & Funds \\
\hline
\end{tabular}

Source: Prepared by the authors.

The four companies surveyed have different profiles, two are hybrid, one is a social business and the other is a cooperative. All of them are influenced by external institutions that are private initiatives and that, in some way, consume products or services of social companies generating funds for them. The descriptions of the surveyed social companies are described below:

a) Copmed02 is a recycling cooperative, which operates with 41 members, from a group of waste pickers and unemployed young people from Favela Vila Prudente. It was a pioneering initiative, where employees can earn up to $\mathrm{R} \$ 3,000$ per month, according to the production presented. In 11 years, it became the first cooperative to collect 24 hours a day, with a flexible hourly people management system based on companies $Y$ and following the new trends of working with flexible hours, goals, and paid for production.

b) Hibmed02 is a digital platform that optimizes research, diagnoses, and manages the social investment of its customers. An artificial intelligence system for managing data related to more than 30,000 social activities, since 1992 it is possible to fully understand the ecosystem of cultural, sports and health projects approved by Brazil's incentive policies. Guarantee the qualification of the sponsor and the social project for making strategic decisions, effectively connecting the objectives and positively impacting society.

c) Hibmed03 is a startup company offering exclusive forms of payment for public transport that can integrate urban passenger transport systems on a global scale. The objective is to transform the urban passenger transport system into one which is versatile and flexible, and to integrate different cities, systems, and methods through technology. The company's project aims to use an application on the smartphone to replace any other form of payment. When creating an account in the system, the user can acquire and manage points, in addition to using the smartphone itself in the transport validator. 
d) Negsocgr01 is an unprecedented initiative created by a large financial company in 2003. Over the past 15 years, it has inspired the culture of giving in Brazil, completed its cycle of success, and ended its activities in December 2018. The fundraising event connects society organizations civil society and its social and environmental projects to social investors, making it possible to raise more than R \$ 19 million, foreseen for 190 projects in Brazil.

Chart 7 presents the results of question 2, referring to how the researched social companies use ICTs, in accordance with the indicators based on the constructs elaborated by Hutchinson; Molla (2009) adapted from Alter (2007), which was presented in Chart 3 of this article.

Chart 7

Answers to question 2 of the surveyed social companies

\begin{tabular}{|c|c|c|c|c|}
\hline Company & ICT infrastructure & $\begin{array}{l}\text { Information } \\
\text { systems }\end{array}$ & ICT in Internal Business & $\begin{array}{l}\text { ICT in external } \\
\text { affairs }\end{array}$ \\
\hline Copmed02 & $\begin{array}{l}\text { Office computer network, } \\
\text { Landline Phone, Fax, Cellular, } \\
\text { E-mail, PCs, Internet, Firewall, } \\
\text { Website, }\end{array}$ & $\begin{array}{l}\text { Administrative, } \\
\text { Management, } \\
\text { Communication. }\end{array}$ & $\begin{array}{l}\text { Internal Communication, } \\
\text { Administration }\end{array}$ & $\begin{array}{c}\text { External } \\
\text { communication } \\
\text { with customers } \\
\text { / clients / } \\
\text { suppliers, }\end{array}$ \\
\hline Hibmed02 & $\begin{array}{l}\text { Office computer network, } \\
\text { Landline Phone, Fax, Cellular, } \\
\text { Email, PCs, Internet, Firewall, } \\
\text { Website, Server for platform }\end{array}$ & $\begin{array}{l}\text { Administrative, } \\
\text { Management, } \\
\text { Communication, } \\
\text { Platform }\end{array}$ & $\begin{array}{l}\text { Internal Communication, } \\
\text { Business as Process, } \\
\text { Procedures, } \\
\text { Administration, External } \\
\text { Business Functions }\end{array}$ & $\begin{array}{l}\text { Digital } \\
\text { platform }\end{array}$ \\
\hline Hibmed03 & $\begin{array}{l}\text { Office computer network, } \\
\text { Landline Phone, Fax, Cellular, } \\
\text { Email, PCs, Internet, Firewall, } \\
\text { Website, Server for platform }\end{array}$ & $\begin{array}{l}\text { Administrative, } \\
\text { Management, } \\
\text { Communication, } \\
\text { Platform }\end{array}$ & $\begin{array}{l}\text { Internal Communication, } \\
\text { Business as Process, } \\
\text { Procedures, } \\
\text { Administration, External } \\
\text { Business Functions }\end{array}$ & $\begin{array}{l}\text { Digital } \\
\text { platform }\end{array}$ \\
\hline Negsocgr01 & $\begin{array}{l}\text { Office computer network, } \\
\text { Landline Phone, Fax, Cellular, } \\
\text { Email, PCs, Internet, Firewall, } \\
\text { Website, Server for platform }\end{array}$ & $\begin{array}{l}\text { Administrative, } \\
\text { Management, } \\
\text { communication, } \\
\text { platform, ERP, } \\
\text { CRM } \\
\end{array}$ & $\begin{array}{l}\text { Internal Communication, } \\
\text { Business as Process, } \\
\text { Procedures, } \\
\text { Administration, External } \\
\text { Business Functions }\end{array}$ & $\begin{array}{l}\text { Digital } \\
\text { platform }\end{array}$ \\
\hline
\end{tabular}

Source: Prepared by the authors.

All companies use ICTs in operational and management functions, maintain a small ICT infrastructure, with emphasis on the use of digital platforms. The use of digital platforms by ESs provides a range of economic or social values. On its own digital platform, the economic result (value) obtained is greater because it allows all control over the processes and services provided by the company.

Chart 8 presents the constructs referring to question 3, that is, beneficiaries, forms of support, economics and social audit, and social mission indicators, which are the indicators based on the constructs in Chart 4 of the framework by Hutchinson and Molla (2009) adapted from Alter (2007). 
Chart 8

Answers to question 3 of the surveyed social companies

\begin{tabular}{|c|c|c|c|c|}
\hline Company & Beneficiaries & $\begin{array}{l}\text { Forms of } \\
\text { Support }\end{array}$ & $\begin{array}{l}\text { Economics and } \\
\text { social audit }\end{array}$ & Social Mission Indicators \\
\hline Copmed02 & Cooperate & Employment & Yes & $\begin{array}{l}\text { Generation of work and income for the } \\
\text { members. }\end{array}$ \\
\hline Hibmed02 & $\begin{array}{l}\text { Civil Society } \\
\text { Organization } \\
\quad(\mathrm{CSO})\end{array}$ & $\begin{array}{c}\text { Service } \\
\text { Development }\end{array}$ & Yes & $\begin{array}{l}\text { More than } 80 \text { clients (NGOs, CSOs } \\
\text { and others) used and obtained resources } \\
\text { through the platform }\end{array}$ \\
\hline Hibmed03 & $\begin{array}{l}\text { Public } \\
\text { transport user }\end{array}$ & $\begin{array}{c}\text { Service } \\
\text { Development }\end{array}$ & Yes & $\begin{array}{l}\text { In the first } 6 \text { months, } 150 \text { thousand public } \\
\text { transport tickets were sold in Sáo Paulo. }\end{array}$ \\
\hline Negsocgr01 & $\begin{array}{l}\text { Civil Society } \\
\text { Organization } \\
\quad(\mathrm{CSO})\end{array}$ & $\begin{array}{c}\text { Service } \\
\text { Development }\end{array}$ & Yes & $\begin{array}{l}\text { Approximately } \mathrm{R} \$ 19 \text { million was raised } \\
\text { for projects across Brazil }\end{array}$ \\
\hline
\end{tabular}

Source: Prepared by the authors.

Two social companies surveyed (Hibmed02 and Negsocgr01) develop project capture services for the Civil Society Organization (CSO); Hibmed03 offers a service to purchase public transport credit for users through social networks, and Copmed02 sells recyclable material and its efforts are converted into employment and income for its members. All companies maintain an internal audit on income acquisition projects and processes.

The results observed in the six indicators (access to markets, income generation, employment opportunities, social training, strengthening of relationships with the sponsor and social outsourcing) are shown in Chart 9, which are the indicators in Chart 5 of the Hutchinson and Molla framework (2009) adapted from Alter (2007).

Chart 9

Results of the performance indicators of social enterprises and their market indexes, income, opportunities, training and strengthening

\begin{tabular}{|l|c|c|c|c|c|c|}
\hline Company & $\begin{array}{c}\text { Market } \\
\text { Access }\end{array}$ & $\begin{array}{c}\text { Income } \\
\text { generation }\end{array}$ & $\begin{array}{c}\text { Employment } \\
\text { Opportunities }\end{array}$ & $\begin{array}{c}\text { Social } \\
\text { training }\end{array}$ & $\begin{array}{c}\text { Strengthening of } \\
\text { relationships with } \\
\text { the Sponsor }\end{array}$ & $\begin{array}{c}\text { Social } \\
\text { Outsourcing }\end{array}$ \\
\hline Copmed02 & yes & yes & yes & yes & yes & no \\
\hline Hibpeq01 & yes & yes & no & no & yes & yes \\
\hline Hibmed02 & yes & yes & no & no & yes & yes \\
\hline Negsocgr0 & yes & yes & no & no & yes & yes \\
\hline
\end{tabular}

Source: Prepared by the authors.

The four social companies surveyed have clearly defined their social missions, as shown in Chart 5 . However, the greatest difficulty was to verify how ICTs can contribute to the mission of these companies.

In this sense, the indicators were used to help demystify this issue and, based on them, it can be observed that:

a) Two indicators "Access to markets" and "Income generation" were identified in all companies. The fact that ICTs allow the extrapolation of physical boundaries to connect with other companies for communication, business, and other items meant that new sources of income 
could be obtained as an e-commerce, marketplace, or simply receiving the order from a supplier through the website or email.

b) The employment opportunity indicator focuses on preparing the beneficiary for the opportunities that may arise, some of them linked to the use of technologies such as programming, use of platforms etc. Only in one of the social companies was this indicator identified.

c) The indicator "social qualification" was found in a social enterprise, the low number can be explained because in this indicator, the qualification refers to some formal process for training the beneficiaries in ICTs. The previous indicator, employment opportunity, is a direct consequence of this training.

d) The indicator "strengthening the relationship with the sponsor" was identified in all the companies surveyed, that is, ICTs help in communication, but effectively its main contribution is the strengthening of the relationship which results in other forms of collaboration.

e) Platform outsourcing or social outsourcing is offered by three social companies that participated in this research and it was found that offering only the service to the beneficiary is interesting for the dissemination and use of the service.

Analyzing these indicators in these companies allowed us to realize that if only one of these indicators is identified in the social enterprise, it can be said that ICTs offer some type of benefit to the company.

\section{CONCLUSION}

After analyzing the results presented by the four companies, which were the object of study in this research, it was found that, despite having different profiles, they suffer influences from external companies, from private initiatives, who consume their products or services and contribute to the generation income. This proved the new organizational model of social companies that represents a change in the search for sustainable development at all levels, financial, social and environmental.

The "mixed value proposal" reflects the integration of the dual mission of social enterprises, as seen in their profiles. Because of the nature of social enterprises, ICTs bring direct benefits, assisting in their global mission and in creating their value proposition, thus bringing a series of advantages to their beneficiaries.

As benefits (in accordance with item 2.4 .3 of this article), companies have used ICTs for operations and management purposes and, for that, maintain small infrastructure, a fact that encourages the use of digital platforms for the generation of both economic and social values.

The use of six indicators: access to markets, income generation, employment opportunities, social training, strengthening of relations with the Sponsor and social outsourcing helped to verify what, in fact, the social mission of these companies is. In this sense, it was found that if companies present at least one of these indicators, ICTs, in fact, can bring some kind of benefit. This provided a more realistic view of the benefits obtained.

The set of indicators should be expanded to include other indicators that will be obtained with future studies on this theory. 
The limitations of this study are due to methodological choices. When opting for a case study, the questioning for companies meant that the results could not be generalized.

For future research, instruments will be used to obtain more accurate data from social enterprises.

\section{REFERENCES}

ACI. Aliança Cooperativa Internacional. 2018. Available inhttps://www.ica.coop/en/cooperatives/ what-is-a-cooperative accessed in $01 / 01 / 2018$

Alegre, Inês; Berbegal-Mirabent, Jasmina. 2016 Social innovation success factors: hospitality and tourism social enterprises. International Journal of Contemporary Hospitality Management, v.28, n. 6, p. 1155-1176.

Alter, S. K. 2007 Social Enterprise Typology [online]. Virtue Venture LLC.

Arena, Marika et al. 2018 Unlocking finance for social tech start-ups: Is there a new opportunity space? Technological Forecasting and Social Change, v. 127, p. 154-165.

Barki, E.; Comini, G.; Cunliffe, A.; Hart, S.; Rai, S. 2015 Social entrepreneurship and social business: Retrospective and prospective research. Revista de Administração de Empresas, 55(4), p. 380-384.

Battilana, Julie; Dorado, Silvia. 2010 Building sustainable hybrid organizations: The case of commercial microfinance organizations. Academy of management Journal, v. 53, n. 6, p. 1419-1440.

Battiliana, J.; Lee, M.; Walker, J.; \& Dorsey, C. 2012 In search of the hybrid ideal. Stanford Social Innovation Review, v. 10, n. 3, p. 50-55.

Besharov, M. L. 2013 Toward a relational ecology of identification: A process model of managing identification based on divergent values. Working paper, Cornell University, Ithaca, NY.

Borzaga, Carlo; DEfourny, Jacques 2001 (Ed.). The emergence of social enterprise. Psychology Press.

Brozek, Kathy O. 2009 Exploring the continuum of social and financial returns. San Francisco: Federal Reserve Bank of San Francisco.

Buchko, Tetiana. 2018 Social Entrepreneurship and Its Implications for Hungary. Periodica Polytechnica. Social and Management Sciences, v. 26, n. 1, p. 38.

Comini, G.; Barki, E.; Aguiar, L. T. D. 2012 A three-pronged approach to social business: A Brazilian multi-case analysis. Revista de Administração (Sáo Paulo), 47(3), p. 385-397.

Dacin, Peter A.; Dacin, M. Tina; Matear, Margaret. Social entrepreneurship: Why we don't need a new theory and how we move forward from here. The academy of management perspectives, v. 24, n. 3, 2010, 37-57.

Davison, R. M.; Harris, R. W.; Vogel, D. R. 2005 E-commerce for community-based tourism in developing countries. In Proceedings of the 9th Pacific Asia Conference on Information Systems. Bangkok.

Dees, J. G. 1998. The meaning of social entrepreneurship.

Defourny, J.; Nyssens, M. 2008a Conceptions of Social Enterprises in Europe and the United States: Convergences and Divergences. HIVA Working Paper, 20p.

Defourny, J.; Nyssens, M.; 2008b Social Enterprise in Europe: Recent Trends and Developments. Social Enterprise Journal 4 (3), 202-228.

Defourny, Jacques; Nyssens, Marthe. 2010 Conceptions of social enterprise and social entrepreneurship in Europe and the United States: Convergences and divergences. Journal of social entrepreneurship, v. 1, n. 1, p. $32-53$. 
BBR

18

Deraedt, E. 2009 Social enterprise: a conceptual framework. Conceptual Discussion Paper for the ILO social Enterprise Developing Targeting Unemployed Youth in South Africa (SETYSA) project.

DTI. 2002.Unit, Social Enterprise. Social Enterprise: A Strategy For Success. London: Department For Trade And Industry

Eisenhardt, K. M. 1989 Building theories from case study research. Academy of Management Review, $14(4)$, p. 532-550.

Granados, Maria L. et al. 2001 Social Enterprise And Social Entrepreneurship Research And Theory: A Bibliometric Analysis From 1991 To 2010. Social Enterprise Journal, V. 7, N. 3, p. 198-218.

Gupta, Anil; DEY, Anamika; SINGH, Gurdeep. 2017 Connecting Corporations And Communities: Towards A Theory Of Social Inclusive Open Innovation. Journal Of Open Innovation: Technology, Market, And Complexity, V. 3, N. 1, p. 17.

Heeks, R. 2002 Failure, Success and Improvisation of Inforrnation Systems Projects in Developing Countries. Development lnforrnatics Group, IDPM, University of Manchester. Working Paper I I.

Hutchinson, K.; Molla, A. 2009 Mapping the dynamics of social enterprises and ICTD in Cambodia. In Information and Communication Technologies and Development (ICTD), 2009. International Conference on (pp. 163-172). IEEE.

Kerlin, Janelle A. 2006, Social Enterprise In The United States And Europe: Understanding And Learning From The Differences. Voluntas: International Journal Of Voluntary And Nonprofit Organizations, V. 17, N. 3, p. 246.

Konsti-Laakso, Suvi et al. 2016 Participatory Design of a Social Enterprise for Rehabilitees. Work, V. 55, N. 1, p. 145-153.

Lapowsky, Issie. 2011 The Social Entrepreneurship Spectrum: Hybrids. Inc. Com, May

Miguel, P. A. C. 2007, Estudo de caso na engenharia de produção: estruturação e recomendaçóes para sua condução. Production, 17(1), p. 216-229.

Millard, J.; Carpenter, G. 2014. Dig+Simital Technology In Social Innovation: A Synopsis. A Deliverable Of The Project: "The Theoretical, Empirical And Policy Foundations For Building Social Innovation In Europe" (Tepsie), European Commission-7th Framework Programme. European Commission. Dg Research, Brussels, https://cordis.europa.eu/project/id/290771/reporting.

Nicholls, A. 2006, "Introduction: The Meanings Of Social Entrepreneurship", In Nicholls, A. (Ed.), Social Entrepreneurship: New Paradigms For Sustainable Social Change, Press, Oxford University, p. 1-36.

Petrini, M.; Scherer, P.; Back, L. 2016, Modelo de negócios com impacto social. RAE-Revista de Administração de Empresas, 56(2), p. 209-225.

Porter, M.E.; Kramer, M.R., 2011 Creating Shared Value. Harvard Business Review, Fev.-Mar.

Prahalad, C. K.; Hart, S. L. 2002, O pote de ouro na base da pirâmide. HSM Management, 32, p. 14-27.

Reficco, E. 2011 As Empresas Na Sociedade: Os Limites Das Boas Intenções. In: Políticas Sociais: Ideias E Práticas. Editora Moderna: São Paulo.

Ridley-Duff, R.; Bull, M. 2018 Solidarity Co-Operatives: Am Embedded Historical Communitarian Pluralist Approach to Social Enterprise Development?. 
Santos, Filipe; Pache, Anne-Claire; Birkholz, Christoph. 2015 Making Hybrids Work: Aligning Business Models And Organizational Design For Social Enterprises. California Management Review, V. 57, N. 3, p. 36-58.

Smith, W. K.; Gonin, M.; Besharov, M. L. 2013 Managing Social-Business Tensions: A Review And Research Agenda For Social Enterprise. Business Ethics Quarterly, 23(3), p. 407-442.

Stake, R. E. 1995 The art of case study research. Sage.

Yin, R.K., 2010 Estudo de caso: planejamento e métodos. Porto Alegre: Bookman.

Yunus, M., 2007 Creating a world without poverty: social business and the future of capitalism. Public Affairs.

Yunus, M.; Moingeon, B.; Lehmann-Ortega, L. 2010. 2010 Building Social Business Models: Lessons from the Grameen Experience. Long Range Planning,43(2-3), p. 308-325.

\section{AUTHOR'S CONTRIBUTION}

MO: $50 \%$

Conceptualization (Lead), Data curation (Lead), Formal analysis (Lead), Investigation (Lead), Methodology (Lead), Project administration (Lead), Resources (Lead), Software (Supporting), Supervision (Supporting), Validation (Lead), Visualization (Lead), Writing-original draft (Lead) and Writing-review \& editing (Lead)

CL: $25 \%$

Conceptualization (Supporting), Formal analysis (Supporting), Investigation (Supporting), Methodology (Supporting), Writing-original draft (Supporting) and Writing-review \& editing (Supporting)

RBP: $25 \%$

Data curation (Supporting), Formal analysis (Supporting), Investigation (Supporting), Project administration (Supporting), Writing-original draft (Supporting) and Writing-review \& editing (Supporting)

\section{CONFLICTS OF INTEREST}

The authors declare that there are no conflicts of interest. 